\title{
Fuel Cell Heating System a Meaningful Alternative to Today's Heating Systems
}

\author{
Robert Staiger and Adrian Tantau
}

\begin{abstract}
Fuel cell heating FCH) systems are now available mostly from gas appliances manufacturers. After a ten-year test phase, these devices are a considered promising alternative on the heating market for disposal. These new heating systems devices could open a new market Segment with new opportunities and new business models. Fuel Cell's in compare to a Carnot process shows a far higher efficiency with less emission. FC heating systems using the thermal energy for heating and the electricity for feed-in. These systems are called combined heat and power plants (Micro CHP). The fuel of this new FCH system is fossil gas. The existing FCH systems are not powerful enough for the energy demand of standard buildings. For this reasons on top of this new FCH systems a condensing gas boiler driven with a fossil gas source is integrated.

This article attempts to compare the FCH System with present alternative heating systems and try to answer question from an environmental and economic view and give alternative outlooks to this kind of heating technology.

Methodologically a model is used to show the dependency of environmental and economic factors. The economic and technical data's are based on latest manufacturing and research institutions.
\end{abstract}

Index terms-Fuel cells (FC), fuel cell heating (FCH), combustion heat and power (CHP), micro CHP, heating innovation.

\section{INTRODUCTION}

Fuel Cells as an alternative device for producing electricity and thermal energy is invented over 170 years ago from Sir W. Grove and C.F. Schönbein [1]-[3] in the same time combustion engine were invented. Unfortunately, on that time materials for fuel cells and the technology state was not high enough to go further. As well the new steam engines and especially the fossil fuel was cheap available on that time. In the 1960th because of the space program fuel cell are developed further more. The first energy crises in the 70th and the following energy crises [4], [5] up to date more research work was done. Today we have a variation of different fuel cell types [6] and application on the market [7], [8], [9]. A fuel cell is a device (chemical energy converter), which takes $\mathrm{H}_{2}$ and $\mathrm{O}_{2}$ as a fuel. The output for this "cold burning process" is thermal energy and electricity [10]. The "exhaust" is poor water $\left(\mathrm{H}_{2} \mathrm{O}\right)$. Depending of the type of fuel cell the electrical efficiency, size of the fuel cell, operation temperature output and the type and quality of fuel varies which shows Table I. The efficiency of a fuel cell is defines [11]-[15]:

Manuscript received September 7, 2015; revised December 23, 2015.

Robert Staiger and Adrian Tantau are with Bucharest University of Economic Studies, Bucharest, Romania (e-mail: rob.staiger@gmail.com, ad_tantau@yahoo.com).

$$
\begin{gathered}
\eta_{F C \text { max }}=\frac{\text { produced amount of energy }}{\Delta H} \\
\eta_{F C \text { elec.max }}=\left(1-\frac{T * \Delta S}{\Delta H}\right) \times 100 \% \\
\eta_{F C}=\eta_{\text {syst }} \eta_{F \max } \eta_{\text {Elec.max }}
\end{gathered}
$$

where $H=$ enthalpy, $S=$ entropy of reaction

The overall fuel cell efficiency of today's micro Fuel cell (CHP) system is around 85-100\% depending of the type of

\begin{tabular}{|c|c|c|c|c|c|}
\hline Type & Fuel Type & $\begin{array}{c}\text { Operation } \\
\text { Temp }{ }^{\circ} \mathrm{C}\end{array}$ & \begin{tabular}{|c|} 
Elect. \\
Efficiency \\
$\%$
\end{tabular} & $\begin{array}{l}\text { Energy } \\
\text { density } \\
\mathrm{W} / \mathrm{cm}^{2}\end{array}$ & Applications \\
\hline $\begin{array}{c}\text { AFC } \\
\text { Alkaline FC }\end{array}$ & $\mathrm{H} 2$ & $60-80^{\circ} \mathrm{C}$ & $60 \%$ & & $\begin{array}{c}\text { Space program, } \\
\text { Military } \\
\text { (submarines) }\end{array}$ \\
\hline $\begin{array}{c}\text { PEFC } \\
\text { Proton } \\
\text { Exchange }\end{array}$ & $\begin{array}{c}\mathrm{CH} 3 \mathrm{OH} \\
\text { Methanol }\end{array}$ & $80^{\circ} \mathrm{C}$ & $40-50 \%$ & & $\begin{array}{l}\text { Power supplies, } \\
\text { Car/Bus, Home } \\
\text { heating, CHP, } \\
\text { USV up to } 250 \mathrm{~kW}\end{array}$ \\
\hline \begin{tabular}{|c|} 
DMFC \\
Direct \\
Methanol \\
\end{tabular} & $\mathrm{H} 2$ & $80-100^{\circ} \mathrm{C}$ & $40-50 \%$ & $0,6 \mathrm{~W} / \mathrm{m}^{2}$ & $\begin{array}{c}\text { Development } \\
\text { phase }\end{array}$ \\
\hline \begin{tabular}{|c|} 
PAFC \\
Phosphoric \\
Acid \\
\end{tabular} & $\mathrm{H} 2$ & $200^{\circ} \mathrm{C}$ & $40-45 \%$ & $0,2 \mathrm{~W} / \mathrm{m}^{2}$ & $\begin{array}{c}\text { CHP's, Power } \\
\text { generators > MW }\end{array}$ \\
\hline \begin{tabular}{|c|} 
MCFC \\
Molten \\
Carbonate \\
FC
\end{tabular} & $\begin{array}{c}\mathrm{H} 2(\mathrm{CH} 4) \\
\text { Biogas }\end{array}$ & $650^{\circ} \mathrm{C}$ & $55-60 \%$ & $0,1 \mathrm{~W} / \mathrm{m}^{2}$ & $\begin{array}{c}\text { CHP's, Power } \\
\text { generators > MW }\end{array}$ \\
\hline $\begin{array}{c}\text { SOFC } \\
\text { Solid FC }\end{array}$ & $\mathrm{H} 2(\mathrm{CH} 4)$ & $800-1000^{\circ} \mathrm{C}$ & $60 \%$ & $0,4 \mathrm{~W} / \mathrm{m}^{2}$ & $\begin{array}{c}\text { Home heating, } \\
\text { power generators }\end{array}$ \\
\hline
\end{tabular}
FC and the calculation method of $\mathrm{NCV}(\mathrm{Hl})$ and GCV $(\mathrm{Hh})$ of the fuel [16].

\section{A. The Function Principal of a Proton Exchange Membrane FC}

Fig. 1 shows the chemical reaction of a Proton Exchange Membrane Fuel Cell, PEMFC. The entire chemical reaction can be described by the equation:

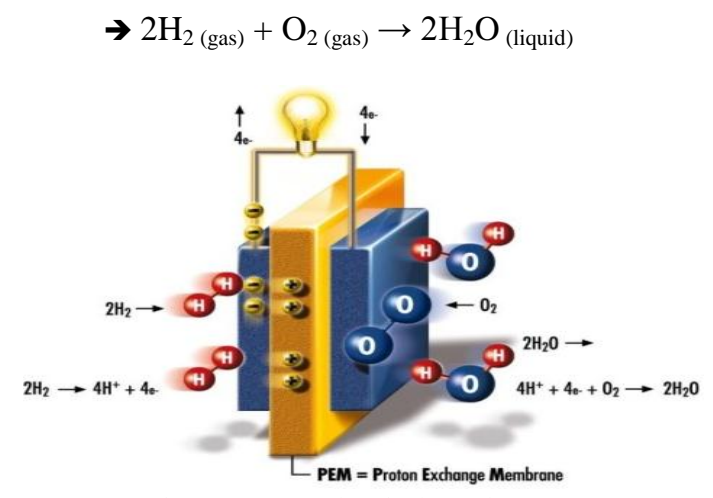

Fig. 1. PEMFC chemical reaction [19]. 


\section{B. Fuel Cell Heating Systems}

Alternative Heating appliances with an integrated "chemical energy converter" (Fuel Cell) which operates with $\mathrm{H}_{2}$ is far more efficient as a Carnot cycle system. The FCH System produces thermal and electrical energy like in a conventional CHP System. Today's FCH Systems are using fossil gas for operation. To operate the $\mathrm{FC}, \mathrm{H}_{2}$ is necessary. For this reason, a reformer is used to generate the $\mathrm{H}_{2}$ part out of a fossil fuel like $\mathrm{CH}_{4}$. The efficiency of a standard reformer is around $80 \%$ depending of caloric value of the fuel [20]. The chemical equation for this reforming process is:

$$
\mathrm{CH}_{4}+2 \mathrm{H}_{2} \mathrm{O} \rightarrow 4 \mathrm{H}_{2}+\mathrm{CO}_{2}
$$

The amount of $\mathrm{CO}_{2}$ of the reforming process can be calculated with the chemical stoichiometry. Molecular mass are : Methane $=16 \mathrm{~g}$, Carbon Dioxide $=44 \mathrm{~g}$, Water 18g, Hydrogen $=1 \mathrm{~g}$ [periodic]

Molecular mass equation: $16 \mathrm{~g}+36 \mathrm{~g}=8 \mathrm{~g}+44 \mathrm{~g} \rightarrow 1 \mathrm{~kg} \mathrm{H}_{2}$ $\rightarrow 5.5 \mathrm{~kg} \mathrm{CO} 2$

With the energy contents of $33.33 \mathrm{kWh} / \mathrm{kg} \mathrm{H} \mathrm{H}_{2} \rightarrow \mathrm{CO}_{2}$ equivalent $\rightarrow 166 \mathrm{~g} \mathrm{CO}_{2} / \mathrm{kWh}$

This calculation procedure is used for the environmental impact in Sections II-III. To compare a condensing gas boiler for burning fossil gas $0.24 \mathrm{kgCO}_{2} / \mathrm{kWh}$ will be emitted in compare to $0.17 \mathrm{~kg} \mathrm{CO}_{2} / \mathrm{kWh}$ with a $100 \%$ efficient reformer.

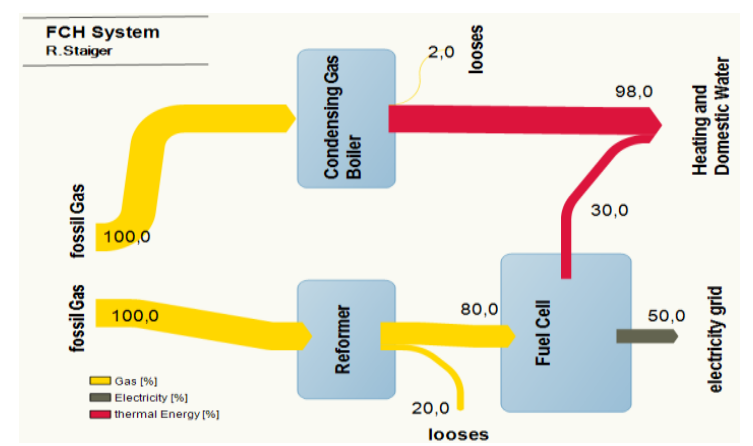

Fig. 2. FCH System and their efficiency dependencies contribution R. Staiger.
Today's FCH systems are not powerful enough to cover the thermal energy demand in standard buildings. For this reasons on top of the FCH System a condensing gas boiler is integrated. Fig. 2 shows the efficiency dependency.

\section{Fuel Cell Heating Systems}

Typical heating appliances show in Table II and the percentage of installations in German homes. Nearly $70 \%$ of heating appliances are older than 10 years and not in the latest technology [21], [22]. From 2017 the new EPBD [23] will banned normal fossil fuel boilers (Gas/Oil) through the calculation procedure for the primary energy factor in new and existing Buildings. All private as well public new buildings from 2018 should be nearly zero energy buildings through EU law [24].

TABLE II: ESTIMATIONS OF HEATING APPLIANCES TODAY IN GERMANY

\begin{tabular}{|c|c|c|}
\hline Type & $\begin{array}{c}\text { Number of heat generator in } \\
\text { Germany }\end{array}$ & Percentage $\%$ \\
\hline Oil/Gas & 14 Mio & $70 \%$ \\
\hline Condensing oil/gas & 4,8 Mio & $23 \%$ \\
\hline Heatpumps (HP) & 0,6 Mio & $3 \%$ \\
\hline Fossil CHP & $<0 \ldots$ & 0 \\
\hline Electricity fossil & $<0 \ldots$ & 0 \\
\hline $\begin{array}{c}\text { Pellets/Wood chips, } \\
\text { Gasification logs }\end{array}$ & 0,9 Mio & $4 \%$ \\
\hline FC Heating fossil// ${ }_{2}$ & $\begin{array}{c}\text { Test Phase } \\
\text { Ca 500 units }\end{array}$ \\
\hline
\end{tabular}

3.4 million Boilers from 14 Mill working Boilers for example in Germany are older than 24 years. Much of this waste is in single and two-family houses installed.

$94 \%$ of the heating systems in Germany are driven with fossil energy source. The last 10 years over $600.000 \mathrm{HP}$ systems were installed as an alternative System [25]. Fossil driven Micro CHP's from 2-3 kWh electrical and 8-12 kW thermal output are available on the market. The overall efficiency of this Micro CHP's is higher than a conventional gas boiler and electricity from the grid. Fig. 3 shows the efficiency flow in a Sankey diagram. The total efficiency is $>$ $40 \%$ means less fuel and less $\mathrm{CO}_{2}$ emissions

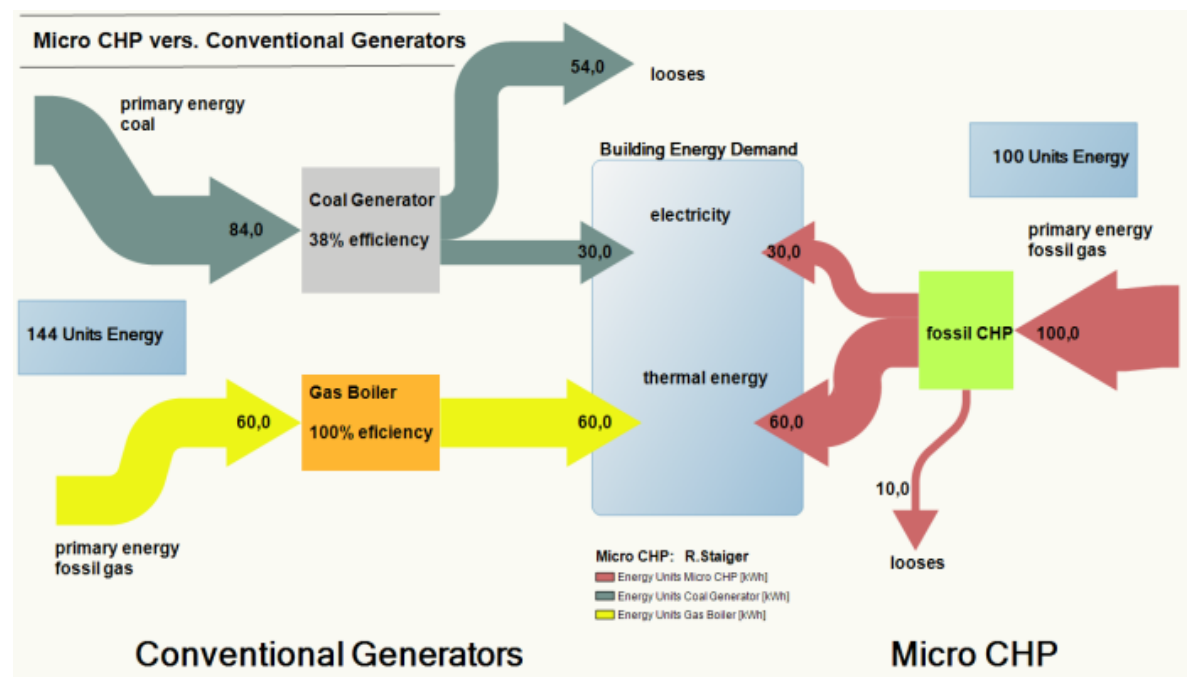

Fig. 3. Comparison micro CHP to conventional generator and gas boiler contribution R.Staiger.

\section{METHODICALLY}

Data's from field test trials in Germany [26], from the EU [27] and from Japan [28], [29] are examined and analyzed.
Detailed data's of the different FCH manufacturer [30] are examined for an environmental and economic analysis. With a heat appliance model (Fig. 4) the analysis and conclusion are compared. 


\section{A. Heating Appliances Model}

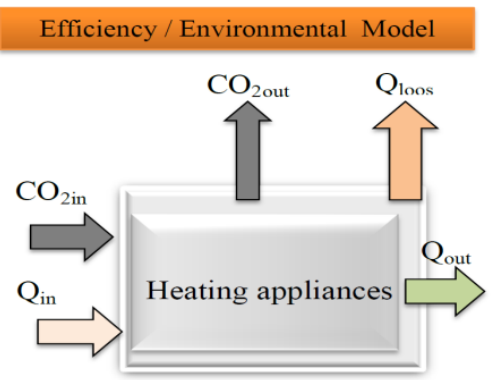

Fig. 4. Model contribution R.Staiger.

All heating appliances have in common a flow of Energy going IN and a flow of energy going OUT. The Energy flows OUT of the appliances are usable and not usable energy (looses). Energy IN is different primary and secondary energy sources like fossil fuel, electricity, renewable sources (geothermal, PV, Biomass, Wind ...) and auxiliary Energy for periphery components (pumps, controls, electrical heaters ....). Energy OUT can be thermal, mechanical and electrical. Depending what kind of energy transformation device it is (Carnot process [31] or chemical transformation FC) more or less energy loses (not usable energy) will be generated.

Mathematical equations and simulations are done with software packages from ETU Köln [32] through the latest EU directives. To calculate and to compare the $\mathrm{CO}_{2}$ emissions and the economic situation on heating appliances one building as a case study is used (see Table III).

For the heat appliances comparison a standard building with following parameters will be used. With a heat demand calculation program the base data's are calculated. For plausibility checks the program is used.

\begin{tabular}{|c|c|c|}
\hline Indices & Parameters & Data's \\
\hline $\mathrm{a}$ & Heated living area & $200 \mathrm{~m}^{2}$ \\
\hline $\mathrm{b}$ & $\begin{array}{l}\text { Energy demand of the building } \\
\text { heating and domestic water } \mathrm{W} / \mathrm{m}^{2}\end{array}$ & $70 \mathrm{~W} / \mathrm{m}^{2}$ \\
\hline $\mathrm{c}$ & $\begin{array}{l}\text { Output Power of the Heat appliances } \\
\underline{P}(a \times b)\end{array}$ & $14 \mathrm{~kW}$ \\
\hline d & Operation hours/a & $1800 \mathrm{~h}$ \\
\hline $\mathrm{e}$ & Thermal energy demand/a $Q_{\text {out }}(c \times d)$ & $25.200 \mathrm{kWh} / \mathrm{a}$ \\
\hline $\mathrm{f}$ & Electricity demand (4-5 people) & $4.000 \mathrm{kWh}$ \\
\hline $\mathrm{g}$ & $\begin{array}{l}\text { Heating System (low temp heating } \\
\text { system } 40^{\circ} \mathrm{C} \text { ) }\end{array}$ & $\begin{array}{l}\text { Underfloor/ } \\
\text { Wallheating }\end{array}$ \\
\hline $\mathrm{h}$ & \multicolumn{2}{|c|}{$\begin{array}{l}\text { Energy cost Cent } / \text { Wh Germany: } \\
\text { Gas }=7.48, \text { Oil }=6,21, \text { HP elec. }=21.47, \text { Elect. }=20.38, \text { tariff } \\
\text { feed }=0.09, \text { elect }=0.31, \text { Pellets }=4, \operatorname{Logs}=2.5\end{array}$} \\
\hline $\mathrm{i}$ & \multicolumn{2}{|c|}{$\begin{array}{l}\text { Energy cost Cent } / \mathrm{kWh} \text { Romania: } \\
\text { Gas }=5.18, \text { Oil }=5.8, \text { HP elect. }=14, \text { Elect. }=14, \text { tariff feed }= \\
0.0, \text { Pellets }=3.5, \text { Logs }=2\end{array}$} \\
\hline
\end{tabular}

Investment costs from field test systems, future investment outlooks, wholesaler, direct supplier of heating appliances and experience of over 20 years in installing renewable systems are used. Experts from research institutes [38], [39] and heating appliances manufacturer monitor the field test trials in Europe and Germany. Interviews with the users are evaluated and analyzed. The evaluation and analysis are done over the last 8 years field test trail! [40]-[46].

The objective is to compare the different appliances with the FCH System and show the results, advantages, and disadvantages of these systems. With this information, new ideas can be developed and new strategies can be brought forward for heating appliances players (stakeholders).

\section{B. Efficiency and Economic Calculations Method}

$$
\begin{gathered}
\sum Q_{\text {in }}=\sum Q_{\text {out }}+\sum Q_{\text {loos }} \\
\dot{Q_{\text {in }}}=\sum Q_{\text {in }_{1}}+\sum Q_{\text {in }_{2}}+\cdots+\sum Q_{\text {in }_{n}} \\
Q_{\text {out }}^{\cdot}=\sum Q_{\text {out }_{1}}+\sum Q_{\text {out }_{2}}+\cdots+\sum Q_{\text {out }_{n}} \\
Q_{\text {loos }}^{\cdot}=\sum Q_{\text {loos }_{1}}+\sum Q_{\text {loos }_{2}}+\cdots+\sum Q_{\text {loos }_{n}} \\
\eta=\frac{\sum Q_{\text {out }}+\sum Q_{\text {loos }}}{\sum Q_{\text {in }}} \eta=\frac{Q_{\text {out }}+Q_{\text {loos }}}{Q_{\text {in }}}
\end{gathered}
$$

A so called investment factor is used in the analysis. This factor compares a standard condensing gas boiler system with the other heating appliances. In this calculation the basis installation is the same (Underfloor/low temperature system) for all. The distinction is due to the different types of boilers, storage capacities and other unique factors in the technical room. The figures are based on manufacturer and wholesaler figures [47], [48]. The energy cost is based on the German and Romania price structure for retail (Table III). Various political instruments in Germany, like the actual tariff feed system, tax relieve, and financial assistance is considered. In Romania this tariff feed system are not available. The $\mathrm{CO}_{2}$ eq. figures are from GEMIS Database [49] and Information from EU, Germany and Romania statistic offices [50]-[54].

\section{Environmental Calculation Method}

Calculation of $\mathrm{CO}_{2}$ is more complex depending of the heat appliances. For all Carnot cycle processes like gas/fossil and biomass boilers the $\mathrm{CO}_{2}$ emissions are defined through the $\mathrm{CO}_{2}$ eq figures and the amount of Energy for operating the appliances in $\mathrm{kg} \mathrm{CO}_{2}$ per $\mathrm{kWh}$. The GEMIS Simulation program defines the figures for the OECD countries. As well other Data's from National and International organization will be used for plausibility checks .The factor depends, how the energy carrier is produced. For example Pellets as a Biomass source or electricity for the grid system. The factor can differ for each country especially the electricity. A fossil fuel CHP will produce heat and electricity. The total amount of Energy IN (Gas) can be calculated with the $\mathrm{CO}_{2}$ eq figures as well. In addition the electrical energy which is delivered can be subtracted from the substituted electrical energy which is normally used. To compare and to analysis the environmental impact of heating appliances a closer look should be also to the refrigerant in heating appliances like HP. These refrigerants could have a high GWP [55] and will influence the environmental impact balance. Following example shows the impact of the refrigerant of a standard HP. Example: The base is the total energy produced from the HP over the live time. Refrigerant live time 10 years, 1400h/a operation hour, average size of HP $12 \mathrm{~kW}$, refrigerant GWP 3800 and $2.5 \mathrm{~kg}$ refrigerant [56].

\section{Calculation Procedure for GWPF}

$$
\begin{gathered}
G W P F=G W P \times m / P \times t \times \text { livetime }\left[\mathrm{kg} \frac{\mathrm{CO}_{2}}{\mathrm{kWh}}\right] \\
100 \% \text { refrigerant looses } \\
G W P F=3800 \times 2,5 / 12 \times 1400 \times 10 \\
\rightarrow 0,056 \mathrm{~kg} \mathrm{CO} / \mathrm{kWh}
\end{gathered}
$$


This amount of $\mathrm{CO}_{2}$ emission must be included in the $\mathrm{CO}_{2}$ calculations for HP appliances. As well the chemical energy converter (FC) which operates over a reformer with fossil gas will have an environmental impact. It means that a fuel cell system which use fossil emits still $\mathrm{CO}_{2}$ over the reforming process. In our fossil driven $\mathrm{FCH}$ with $80 \%$ reformer efficiency a figure $>0.2 \mathrm{~kg} \mathrm{CO}_{2} / \mathrm{kWh}$ is calculated. In these calculations there is no savings over the reformer and FC devices (similar like a normal burning process). Following Equation can be used for calculating the total $\mathrm{CO}_{2}$ for heating appliances.

$$
\begin{aligned}
\mathrm{CO}_{2 \text { total }}= & \mathrm{CO}_{2 \text { eq. fuelin }} \times Q_{\text {in }}+Q_{\text {in }} \times \mathrm{GWPF}_{\mathrm{HP}}- \\
& \mathrm{CO}_{2 \text { eq.elect }} \times Q_{\text {out elc. }}
\end{aligned}
$$

To compare the economic and $\mathrm{CO}_{2}$ impact for existing heating appliances with the new FCH system, a standard building will be used for this case study. The existing heat appliances are all from Europe. For FCH systems, Japan has installed more than 50.000 Units. With the "enefarm" [57] program the Japanese government pushed this technology in the market (especially after the Fukushima disaster). Panasonic and Toshiba are the leading companies in this field. In Europe enefield [58] as a European program up to date 500 systems are in field test.

\section{RESEARCH ANALYSIS AND RESULTS}

The calculation procedure depends on the following factors.

- The average energy efficiency of heat appliances shows Table IV row 1. Depending of the quality of the devices and the installation the variation can be enormous. For the calculation methods, an average efficiency is taken from technical data of heating appliances. For Micro $\mathrm{CHP}$ an electrical and thermal efficiency is taken.

- The total amount of energy (Table IV row 2) for the heat appliances the average efficiency factor is used. The basis for the thermal energy amount (heating/DW) is for all heating appliances calculation the same. For Micro $\mathrm{FCH}$ system the electrical energy is the base $(4.000$ $\mathrm{kWh} / \mathrm{a})$.

- The demand of electricity for the building is 4.000 kWh/a (4-5 people).

- The energy price for thermal and electrical Energy is calculated with the average energy prices see Table III.

- The amount of $\mathrm{CO}_{2}$ emissions is depending of the fuel type and the total energy amount. For calculation the $\mathrm{CO}_{2}$ eq the figures from GEMIS is used. For the Fuel Cell heating appliances the amount of energy which is produced over the $\mathrm{FC}$, the $\mathrm{CO}_{2}$ is calculated with theoretical chemical equations and the efficiency of the reformer.

\section{A. Comparison Energy Cost and Energy Savings}

Fig. 5 shows the energy saving potential for installed heating appliances in Germany. For the comparison energy cost and saving potential of the heating appliances, the reference system is the $\mathrm{FCH}$. The $\mathrm{FCH}$ system installed in Germany has the lowest energy cost. The reason for the saving potential is the actual electricity cost $(0.3 € / \mathrm{kWh})$ in Germany, which will be substituted with the FCH system. All other systems are more expensive to run (negative value). Biomass systems have clear advantages through the lower energy prices in compare to fossil driven systems. HP system can vary quit significant depending of the efficiency (SPF) [59] and the electricity prices. Micro CHP's are more complex. Depending of a heat-controlled supply or electrical controlled supply [60]-[62] the savings can vary. In our case study the fossil CHP System is heat controlled, electricity output depends of the thermal energy demand. The electricity is used for direct usages (smart grid) and overcapacity feed back to the grid (tariff feed). A FCH system is different of the size of the chemical converter (FC) and there electrical efficiency. In this case, study the calculation is based on the electricity demand in the building. The thermal demand can be controlled with the internal condensing gas boiler. The advantage of an electrical controlled supply system is significant.

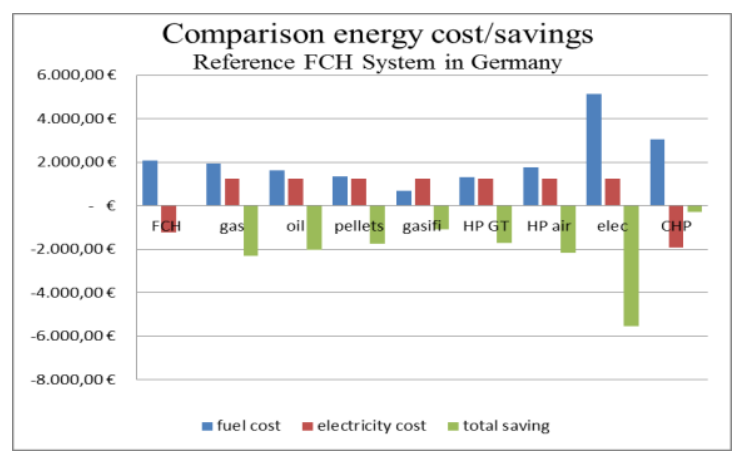

Fig. 5. Contribution R.Staiger.

TABLE IV: GERMANY

\begin{tabular}{|c|c|c|c|c|c|}
\hline Type & Efficiency & $\begin{array}{c}\text { Total } \\
\text { energy kW }\end{array}$ & $\begin{array}{l}\text { Energy } \\
\text { cost } €\end{array}$ & $\begin{array}{c}\mathrm{CO}_{2} \\
\text { emission } \mathrm{kg}\end{array}$ & $\begin{array}{c}\text { Energy cost } \\
\text { elect. } €\end{array}$ \\
\hline gas & 0,98 & 25.714 & 1923 & 6.171 & 1240 \\
\hline oil & 0,96 & 26.250 & 1630 & 7.875 & 1240 \\
\hline pellets & 0,95 & 26.526 & 1352 & 1060 & 1240 \\
\hline gasific & 0,9 & 28000 & 700 & 560 & 1240 \\
\hline HP gt & SPF 4 & 6300 & 1323 & 3780 & 1240 \\
\hline HP air & SPF 3 & 8400 & 1764 & 5040 & 1240 \\
\hline Elect. & 1 & 25200 & 5135 & 15120 & 1240 \\
\hline \multirow{3}{*}{$\begin{array}{l}\text { CHP } \\
10 \mathrm{kw} \\
4064 \mathrm{~h}\end{array}$} & 0,90 & 40.600 & 3036 & 9744 & \multirow{2}{*}{$\begin{array}{c}-1240 \\
-664 \\
\end{array}$} \\
\hline & $28 \%$ el. & 11.380 & & & \\
\hline & $62 \%$ th. & 25.200 & & & \\
\hline \multirow{3}{*}{$\begin{array}{c}\text { FCH } \\
1 \mathrm{kw} \\
\text { el. } 0.8 \\
\text { kw th. }\end{array}$} & 0,90 & 28.000 & 2.094 & 6.720 & \multirow{3}{*}{$\begin{array}{c}-930 \\
-90\end{array}$} \\
\hline & $45 \%$ el. & 4.000 & & & \\
\hline & $35 \%$ th. & $\begin{array}{c}3.000 \\
\text { rest gas } \\
21800\end{array}$ & & & \\
\hline
\end{tabular}

\begin{tabular}{|c|c|c|c|c|}
\hline Type & $\begin{array}{c}\mathrm{CO}_{2} \text { emission } \\
\text { elect. kg }\end{array}$ & $\begin{array}{c}\text { Total energy } \\
\text { cost } €\end{array}$ & $\begin{array}{c}\text { Cost } \\
\text { savings } €\end{array}$ & $\begin{array}{c}\mathrm{CO}_{2} \\
\text { savings kg }\end{array}$ \\
\hline gas & 2.400 & 3.163 & -2309 & -4251 \\
\hline oil & 2.400 & 2870 & -2016 & -5955 \\
\hline pellets & 2400 & 2592 & -1738 & 860 \\
\hline gasific & 2400 & 1940 & -1086 & 1360 \\
\hline HP gt & 2400 & 2563 & -1709 & -1860 \\
\hline HP air & 2400 & 3004 & -2150 & -3120 \\
\hline Elect. & 2400 & 6372 & -5518 & -13200 \\
\hline $\begin{array}{c}\text { CHP } \\
10 k w\end{array}$ & -6828 & 1132 & -278 & 1404 \\
4064h & -2400 & 1.047 & 0 & 0 \\
\hline $\begin{array}{c}\text { FCH } \\
1 \mathrm{kw} \text { el. 0.8 } \\
\text { kw th. }\end{array}$ & & & & \\
\hline
\end{tabular}


Table V shows the calculations with the data's from Romania for energy cost and $\mathrm{CO}_{2}$ emissions.

TABLE V: ROMANIA

\begin{tabular}{|c|c|c|c|c|c|}
\hline Type & Efficiency & $\begin{array}{c}\text { Total } \\
\text { energy kW }\end{array}$ & $\begin{array}{c}\text { Energy } \\
\text { cost } €\end{array}$ & $\begin{array}{c}\mathrm{CO}_{2} \\
\text { emission kg }\end{array}$ & $\begin{array}{c}\text { Energy cost } \\
\text { elect. } €\end{array}$ \\
\hline gas & 0,98 & 25.714 & 1332 & 6.171 & 560 \\
\hline oil & 0,96 & 26.250 & 1522 & 7.875 & 560 \\
\hline pellets & 0,95 & 26.526 & 928 & 1060 & 560 \\
\hline gasific & 0,9 & 28000 & 560 & 560 & 560 \\
\hline HP gt & SPF 4 & 6300 & 882 & 3780 & 560 \\
\hline HP air & SPF 3 & 8400 & 1176 & 5040 & 560 \\
\hline Elect. & 1 & 25200 & 3528 & 15120 & 560 \\
\hline $\begin{array}{c}\text { CHP } \\
10 \mathrm{kw} \\
4064 \mathrm{~h}\end{array}$ & 0,90 & 40.600 & 2103 & 9744 & -560 \\
\cline { 2 - 5 } & $28 \%$ el. & 11.380 & & & -0 \\
\hline $\begin{array}{c}\text { FCH } \\
1 \mathrm{kw} \text { el. } \\
0.8 \mathrm{kw} \\
\text { th. }\end{array}$ & 0,90 & 25.200 & & & -400 \\
\hline
\end{tabular}

\begin{tabular}{|c|c|c|c|c|}
\hline Type & $\begin{array}{c}\mathrm{CO}_{2} \text { emission } \\
\text { elect. } \mathrm{kg}\end{array}$ & $\begin{array}{l}\text { Total energy } \\
\text { cost } €\end{array}$ & $\begin{array}{c}\text { Cost } \\
\text { savings } €\end{array}$ & $\begin{array}{c}\mathrm{CO}_{2} \\
\text { savings kg }\end{array}$ \\
\hline gas & 2000 & 1892 & -833 & -3451 \\
\hline oil & 2.000 & 2082 & -1023 & -5155 \\
\hline pellets & 2.000 & 1488 & -429 & 1660 \\
\hline gasific & 2.000 & 1120 & -61 & 2.160 \\
\hline HP gt & 2.000 & 1442 & -363 & -1060 \\
\hline HP air & 2.000 & 1736 & -677 & -2320 \\
\hline Elect. & 2.000 & 4.088 & -3.029 & -12400 \\
\hline $\begin{array}{c}\text { CHP } \\
10 \mathrm{kw} \\
4064 \mathrm{~h}\end{array}$ & -5690 & 1543 & -484 & 666 \\
\hline $\begin{array}{c}\text { FCH } \\
1 \mathrm{kw} \text { el. } 0.8 \\
\text { kw th. }\end{array}$ & -2000 & 1.059 & 0 & 0 \\
\hline
\end{tabular}

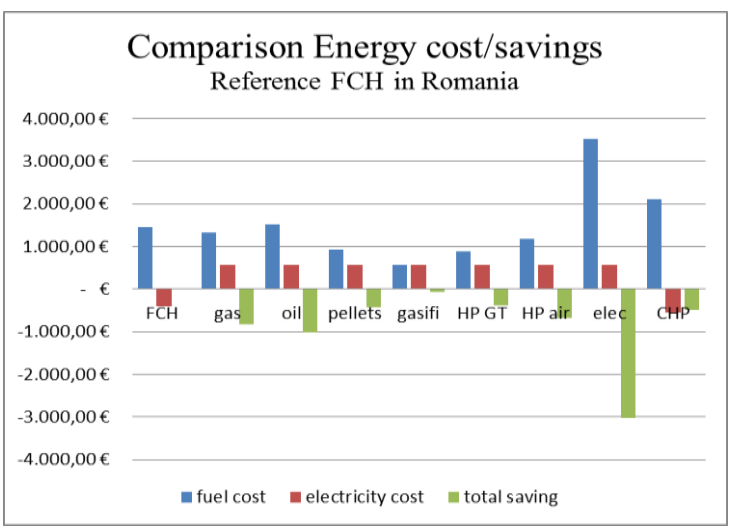

Fig. 6. Contribution R.Staiger.

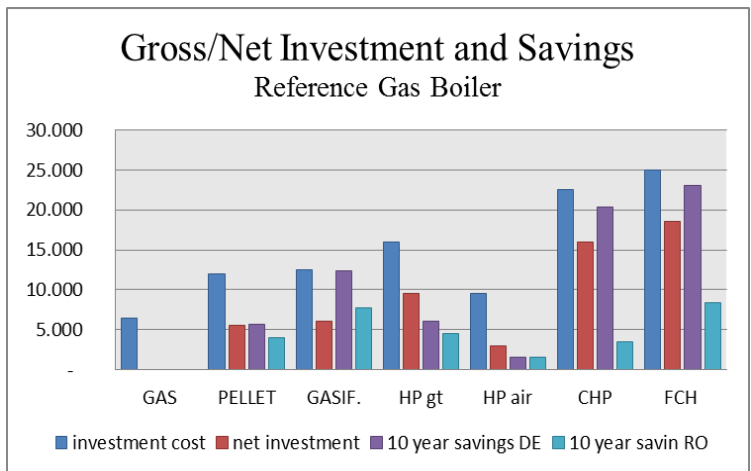

Fig. 7. Contribution R.Staiger.

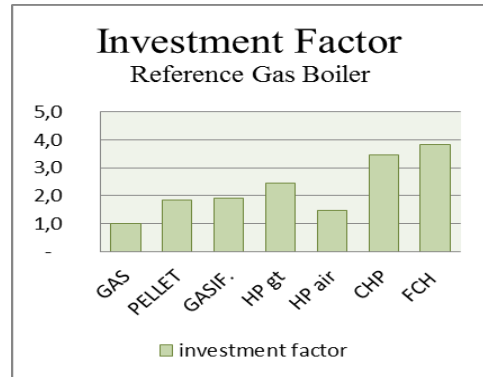

Fig. 8. Contribution R.Staiger.

For comparing energy cost and savings in Romania the reference is the FCH as well (see Fig. 6 and Fig. 7). In this analysis, the FCH System has still the lowest energy cost. But through the lower Energy prices and no tariff feed systems the Micro CHP are not economical to run (see Fig. 8 and Fig. 9).

\section{B. Economic Calculation for Germany/Romania (Reference Condensing Gas Boiler)}

The investment cost and the investment factor is based on average cost of the different appliances. The appliances are standard systems which are available in the EU market. An average figure is used. For FCH system the actual cost are used. A Saving potential of $>40 \%$ can be reached with higher quantities and new innovations in R\&D and production [63]

\section{Investment Comparison}

With an Investment analysis the result shows clearly the dependencies of the energy prices and possible tariff feed programs. Payback times from an energy saving point of less than 10 years in Germany are possible. In compare to Romania it is a factor 2 to 3 higher (see Fig. 9). Attention must be paid with this new Micro CHP system on warranty details, service and maintenance cost in compare to established heating appliances. A full cost accounting should be done to minimize the investment risk. FCH system has the highest investment factor in compare to a standard condensing gas boiler. The reason is using a new unique technology (FC, Reformer) in small quantities with high R\&D costs involved. The Economy of Scale Effects [64] will reduce the prices in the future.

Comparing the savings on $\mathrm{CO}_{2}$ emissions (see Fig. 10) only the Biomass and CHP appliances will have positive effects. Fossil operated heating appliances emitting much more $\mathrm{CO}_{2}$. HP system depending of the SPF can be also quit significant. In comparison with CHP the emissions are negative because of calculating the electricity in the building. Micro CHP's have the potential reducing $\mathrm{CO}_{2}$ emissions. As more electrical energy is produced on side (decentralized systems) for own use with more intelligent controls (smart grid) as higher will be the saving potentials.

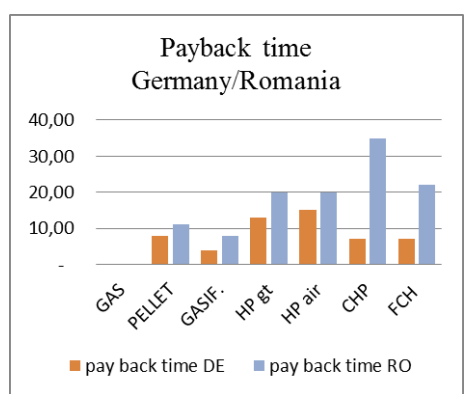

Fig. 9. Contribution R.Staiger 


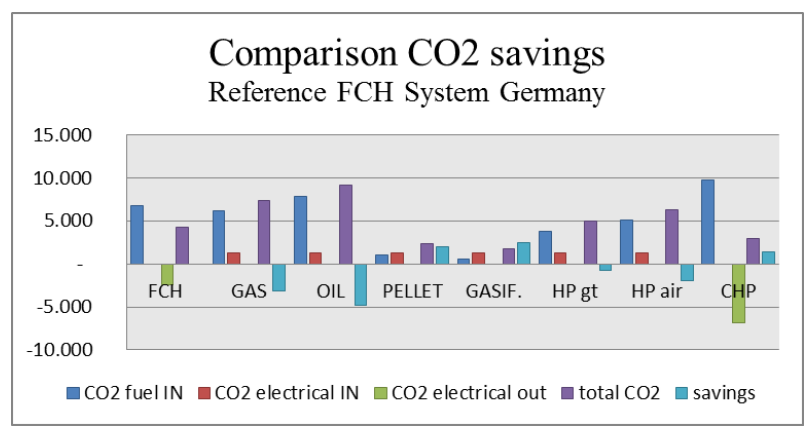

Fig. 10. Contribution R.Staiger

With over 14 Million old heating appliances in Germany the potential saving $\mathrm{CO}_{2}$ is enormous for the future [65].

In Romania the $\mathrm{CO}_{2}$ savings in compare to Germany is for this analysis smaller. The $\mathrm{CO}_{2}$ eq figure in Romania is $0.5 \mathrm{~kg}$ $\mathrm{CO}_{2} / \mathrm{kWh}$ in compare to $0.6 \mathrm{~kg} \mathrm{CO} / \mathrm{kWh}$ in Germany, because of the higher renewable contribution in the electrical network through hydroelectric power plants in Romania [66], [67].

\section{CONCLUSION}

The Analysis shows the FCH system could be an alternative for today's existing heating systems in accordance with the analysis in this article. Through the political intention changing the energy structure in a renewable energy future (Energy transition) in Germany, the tariff feed system and different grand schemes makes it economical feasible installing this kind of FCH systems. Without pushing this technology forward with political instruments like tax relieves, special tariff feed systems, allowances, subsidies, grants contributions, financial assistance, the volumes are too low to achieve a comparable price in compare to today's existing heating systems. The aim for the EU governments reducing greenhouse gas emissions, increasing the efficiency and using less fossil energy sources for independencies this Micro CHP system could be one way to achieve the objectives. With over 14 Million old fossil heating systems alone in Germany this saving potentials for energy efficiency and $\mathrm{CO}_{2}$ reduction in the $\mathrm{EU}$ is enormous. The market potential in domestic houses as well public and industry building is as well huge.

Using a FCH system for replacement of existing heating system and new installation following important point must be considered.

- Micro FCH heating systems are more efficient, it can reduce greenhouse gas emissions, it is noiseless, the FC has a cold burning process with significantly higher efficiency compared to separate production of electricity and heat

- FCH system will deliver thermal and electrical energy. To generate electricity and using this direct in the building (decentralized) makes this device so interesting from an energy cost and environmental point.

- FCH systems are due to their efficiency, flexibility and decentralized applications an ideal module for future energy supply

- Possibility of crosslinking to "virtual power plants"

- Decentralized Micro FCH systems can make an important contribution to grid discharge and stabilization, flexible use and ideal for balancing fluctuating renewable energy sources

- Micro FCH system relocated the production of electrical energy to the local level, avoiding transmission losses

- Micro CHP consumers can strengthen by controlling their electric bill itself (smart grid!)

- Due to the high power to heat ratio and good scalability performance fuel cell heating appliances are also suitable for the renovated existing buildings with low heat demand

- Object related CHP systems, for example with integrated heat storage systems, can supplement the fluctuating of electricity production from wind and solar power quit flexible and helps to stabilize the grid system (seasonal anti correlation to photovoltaics, wind and Power to Heat etc.)

- Installing a FCH is quit more complex as standard biomass or fossil driven systems. This knowledge of installation with good quality is an important issue (similar like HP Systems).

- The correct planning and sizing of a Micro FCH system for saving energy cost and reducing $\mathrm{CO}_{2}$ emissions is essential.

- The different countries with the different political instruments like grands, tariff feed system, electricity cost, gas cost etc. can make this system less economically.

An ideal future outlook for this kind of FCH system would be:

Ideally using instead of a fossil source driving FCH system, a renewable produced $\mathrm{H}_{2}$ gas (carrier) produced locally (decentralized) over biomass reforming processes and electrolysis with Wind and PV Energy.

\section{REFERENCES}

[1] V. Quaschning, Renewable Energy and Climate Protection, 3rd ed. 2013, p. 333.

[2] P. Kurzweil, Fuel Cell Technology, 2nd ed. 2013, pp. 3-4.

[3] S. Geitmann, Energiewende 3.0, 3rd ed. 2012, pp. 140-141.

[4] K. R. Merrill, The Oil Crisis of 1973-1974: A Brief History with Documents, Bedford St. Martin's, 2007, pp. 1-26.

[5] D. Yergin, The Prize: The Epic Quest for Oil, Money, and Power, New York, Simon and Schuster, 2007, pp. 595-680.

[6] P. Kurzweil, Fuel Cell Technology, 2nd ed. 2013, pp. 5-6.

[7] J. Töpler, Hydrogen and Fuel Cell, 2014, pp. 113-167.

[8] A. V. da Rosa, Fundamentals of Renewable Energy Processes, 3rd ed. Amsterdam: Academic Press, 2012, pp. 293-317.

[9] H. Niederhausen, Electrical Current, Springer, 2014, pp. 431-433.

[10] K. Langeheinecke, Thermodynamics for Engineers, 8th ed. 2012, p. 221.

[11] W. Vielstich, Handbook of Fuel Cells: Fundamentals Technology and Applications, Wiley, 2003, ch. I, part 1.

[12] L. Blomen, Fuel Cell Systems Explained, 2nd ed. 1993, ch. 2, pp. 25-43.

[13] L. Jörissen. (Jan. 24, 2008). Fundamentals of Fuel Cells. pp. 3-28. [Online]. Available: http://www.bba-bw.de/files/vortrag_bz-grundlagen-wbzu.pdf

[14] F. Barbir, PEM Fuel Cells: Theory and Practice, Elsevier, 2011, ch. 2 , pp. 17-29.

[15] P. Kurzweil, Fuel cell Technology, 2nd ed. 2013, pp. 22-24.

[16] K. Langeheinecke, Thermodynamics for Engineers, 8th ed. 2012, pp. 300-335.

[17] J. Laminie, Fuel Cell Systems Explains, 2nd ed. 2003, p. 15.

[18] L. Jörissen. (Jan. 24, 2008). Fundamentals of Fuel Cells. pp. 27-35. [Online]. Available: http://www.bba-bw.de/files/vortrag_bz-grundlagen-wbzu.pdf 
[19] H-TEC Picture. H-TEC Education GmbH, Luebeck Germany. [Online] Available:

http://www.h-tec.com/de/education/technologie/elektrolyse/

[20] K. H. Tetzlaff, Hydrogen for All, 3rd ed. 2011, pp. 386-392.

[21] BDH. (2015). Heating Market (Federation of German Heating Industry).

[Online]. http://www.bdh-koeln.de/bdh/bdh-zum-waermemarkt.html

[22] Shell/BDH, Heating Study (How We Heat Tomorrow?), 2013, pp 25-27.

[23] EU- Building Directive, Directive 2010/31/EU of the European Parliament and of the Council on the Energy Performance of Buildings, January 16, 2012.

[24] A. J. Marszal, "Zero energy building," ELSEVIER Energy Building, vol. 43, pp. 971-979, April 2011.

[25] BDEW. (2015). How heats Germany, study on the heating market association of energy and water industries. [Online]. Available: https://www.bdew.de/internet.nsf/res/6F9B1BC993486B78C1257E73 00325F33/\$file/GA\%20GAS_15-001-02_Heizungsmarkt-Brosch\%C3 $\%$ BCre_online.pdf

[26] M. S. Löffler. (2013). Importance of micro-cogeneration with fuel cells - experiences from the project Callux. [Online]. Available: http://www.brennstoffzelle-nrw.de/fileadmin/daten/Workshops/enefie 1d/2_Loeffler_ZSW_Callux_28112013.pdf

[27] Fuel Cell Today, Using Fuel Cell in... Residential Heat and Power, 2012, Japanese Ene-Farm Scheme.

[28] Panasonic. (2015). Panasonic's household fuel cell (ENE FARM). [Online]. Available: http://panasonic.co.jp/ap/FC/en_doc03_00.html

[29] F. Riddoch. (2013). Europe-wide field test micro-CHP systems with fuel cells. [Online]. Available: http://www.brennstoffzelle-nrw.de/fileadmin/daten/Workshops/enefie 1d/3_Reijalt_HyER_enefield-Einfuehrung_28112013.pdf

[30] IBZ, "Fuel cells for domestic energy supply, appliances offers," Initiative Fuel Cell, FCH Manufacturer, 2015.

[31] A. Tantau and R. Staiger, "Energy efficiency model for small/medium geothermal heat pump systems," Management \& Marketing, vol. 10 no. 1, pp. 12-33, June 2015.

[32] ETU. Hottgenroth Software GmbH \& Co. KG, ETU Software GmbH [Online].

Available: https://www.hottgenroth.de/software/energienachweise/energieberater -professional/

[33] Consumer advice center. (2015). Development of energy prices in recent years. [Online]. Available: http://www.vz-nrw.de/link1125445A.html

[34] Eurostat, Prices for Electricity Domestic Consumers, 2007.

[35] Eurostat. (2015). Prices for gas domestic consumer. [Online]. Available:

https://open-data.europa.eu/de/data/dataset/aqDMwMrWaIVNy4eZt2 rYOQ

[36] IEA. Monthly energy prices. [Online]. Available: http://www.iea.org/statistics/relatedsurveys/monthlyenergyprices

[37] Wordpress. Comparing wood fuels prices in 2013 across EU. [Online]. Available:

https://energment.wordpress.com/2013/08/30/comparing-wood-fuelsprices-in-2013-across-eu

[38] P. E. Dodds, "Hydrogen and fuel cell technologies for heating, a review," International Journal of Hydrogen Energy, vol. 40, no. 5, pp. 2065-2083, Feb. 2015.

[39] M. Seidel. (2013). Experience report EWE - more than 400 micro-CHP systems with fuel cells tested in the field (Heating appliances manufacturer monitoring). [Online]. Available: http://www.brennstoffzelle-nrw.de/fileadmin/daten/Workshops/enefie 1d/6_Seidel_EWE_Erfahrungsbericht_28112013.pdf

[40] V. Nerlich, "Cogeneration in single family homes with fuel cell heating appliances," Institute of Energy Research, 2010.

[41] M. Braun. (2013). Europe-wide field test for micro-CHP systems with fuel cells. [Online]. Available: http://www.brennstoffzelle-nrw.de/fileadmin/daten/Workshops/enefie 1d/4_Braun_Baxi_enefield-Technik_28112013.pdf

[42] M. S. Löffler. Importance of cogeneration with fuel cells - experiences from the project Callux. [Online]. Available: http://www.brennstoffzelle-nrw.de/fileadmin/daten/Workshops/enefie 1d/2_Loeffler_ZSW_Callux_28112013.pdf

[43] F. Riddoch. Europe-wide field test micro-CHP systems with fuel cells. [Online]. http://www.brennstoffzelle-nrw.de/fileadmin/daten/Workshops/enefie 1d/3_Reijalt_HyER_enefield-Einfuehrung_28112013.pdf

[44] IFEU, "Ecological and economic analysis of fuel cell heating," 2012.

[45] F. Liehr, "Fuel cell heating appliances in the Bremer House. An economic analysis of modern cogeneration in existing buildings," 2012.
[46] A. Dauensteiner. Concept of a technology implementation program in Germany. [Online]. Available: http://www.brennstoffzelle-nrw.de/fileadmin/daten/Workshops/enefie ld/7_Dauensteiner_Vaillant_Programmkonzept_28112013.pdf

[47] Viessmann Pricelist. (2015/2016). [Online]. Available: http://www.viessmann.ch/de/services/preisliste-2015-2016.html

[48] Fröhling Bomass Systems. (May 2014). Pricelist Germany. [Online]. Available: http://www.pastillepalace.de/Dokumente/ Preisliste/Froeling2014DE_PAPA.pdf

[49] GEMIS Simulation Model V 4.9.

[50] U. Fritsche, "Development of the primary energy factor of electricity generation in the EU28," International Institute for Sustainability Analysis and Strategy, 2015.

[51] U. Fritsche, "The non-renewable cumulative energy consumption of the German power mix in 2013," International Institute for Sustainability Analysis and Strategy, 2014.

[52] P. Icha, "Development of specific carbon dioxide emissions of the German power mix in the years 1990 to 2013," German Federal Environment Agency Dessau, 2014.

[53] IINAS, GEMIS Simulation Model V4.9, 2014

[54] KEA. (2015). $\mathrm{CO}_{2}$ emission factors. [Online]. Available: http://www.kea-bw.de/service/emissionsfaktoren

[55] UNEP. (2012). Handbook for the Montreal protocol on substances that deplete the ozone layer. UNEP United Nations Environment Program. [Online]. Available: http://ozone.unep.org/Publications/MP_Handbook/MP-Handbook-20 12.pdf

[56] A. Tantau and R. Staiger, "Environmental impact model for the assessment of Heatpump systems," 2015.

[57] Enefarm. Enefarm project Japan. [Online]. Available: http://enefield.eu/news/enefield-enefarm-eneware/

[58] Enefield Project. [Online]. Available: http://enefield.eu/

[59] A. Tantau and R. Staiger, "Energy efficiency model for small/medium geothermal heat pump systems," Management \& Marketing, vol. 10, no. 1, pp. 12-33, June 2015.

[60] J. Seifert, "Micro CHP systems in the building sector," Berlin VDE, pp. 5-56, 2013.

[61] W. Suttor, The Micro-CHP. A Heating System That Also Generates Electricity, 5th ed. BINE, 2009, pp. 32-60.

[62] B. Thomas, Micro CHP Units. Fundamentals, Instrumentation, Operational Data, 2nd ed. 2011, pp. 99-106.

[63] B. Groß. (2012). IZES analysis and evaluation of instruments to launch stationary fuel cell systems. [Online]. Available: https://www.ptj.de/lw_resource/datapool/_items/item_4473/bmwi_ma rkteinfhrung_brennstoffzellen_izes-2013.pdf

[64] K. Sander, "Potential and prospects of stationary fuel cells (Scale effect)," 2004

[65] BDH. (2015). BDH for the heating market. [Online]. Available: http://www.bdh-koeln.de/bdh/bdh-zum-waermemarkt.html

[66] G. Grigoras and F. Scarlatache, "An assessment of the renewable energy potential using a clustering based data mining method. Case study in Romania," Energy, vol. 81, pp. 416-429, 2015.

[67] D. Dusmanescu, J. Andrei, and J. Subic, "Scenario for implementation of renewable energy sources in Romania," Procedia Economics and Finance, vol. 8, pp. 300-305, 2014.

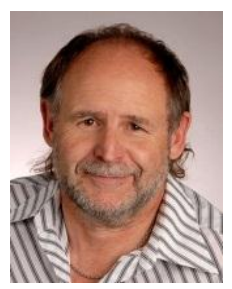

Robert Staiger lives in south of Germany close to the Austrian/Swiss border. After his apprenticeship as a light mechanic, he did a technical degree in mechanical/electrical from University of Applied Science in Furtwangen (Dipl. Ing. (FH)). He also holds various degrees in energy and emissions protection related topics. In 2013, he finished his economic studies (MBA) from University Lah (WHL). In 2014, he started his postgraduate work $(\mathrm{PhD})$ in the field of sustainability, renewable energy and hydrogen as a renewable energy carrier, on Bucharest University of Economic studies.

$\mathrm{He}$ is a CEO in an engineering office for energy efficiency in Germany. In the last decade, he published several patents in the field of heat pumps/fuel cells. His latest patent submission with in his working company in Nov. 2014, described a special refrigeration control unit, using a fuel cell device. He helps in audit processes for ISO 50001 Energy Management Systems and doing technical plausibility checks for NSAI in Dublin. He works as an assessor, auditor and expert for energy efficiency in small medium size Companies (SME), doing energy calculations for existing and low energy buildings for public and private customer for improving efficiencies, reducing greenhouse gases, saving energy and money. He is a member of different institutions and organizations, such as Chamber of Engineers, Energy Advisors Network, Chamber of Skilled Crafts, Chamber of Commerce and Industry. 